\title{
Causes of death in sickle-cell disease in Jamaica
}

\author{
ANTHONY N THOMAS，CATHERINE PATTISON， GRAHAM R SERJEANT
}

\begin{abstract}
A review of the causes of death in 276 patients with sickle-cell disease showed that although the greatest mortality occurred in the first five years of life, roughly one-quarter were aged over 30. Commonest causes of death in the first ten years included acute splenic sequestration, septicaemia, meningitis, aplastic crises, and gastroenteritis. In older patients cerebrovascular accidents and renal failure became common. The acute chest syndrome affected all age groups about equally but appeared to result predominantly from infection in the young and embolism or thrombosis in the old.
\end{abstract}

\section{Introduction}

Most genotypes of sickle-cell disease are associated with a shortened life expectancy, but there is little information on the causes of death or on the pattern of mortality at different ages. Our experience at a major medical centre in the Caribbean over the past 30 years is therefore presented in this retrospective review of the causes of death in 276 patients.

\section{Material and methods}

The patients had attended the University Hospital of the West Indies in Kingston, Jamaica, from its foundation in 1952 up to the present. The population with sickle-cell disease served by this institution has increased generally with time but specifically with the formation of the sickle-cell clinic in 1965 and peripheral sickle-cell clinics in 1967-8, and the start of a cohort study of sickle-cell disease (based on neonatal diagnosis at a large maternity hospital) in 1973.

The diagnostic criteria, as expected, have become more precise with time but since 1957 have generally been based on haemoglobin electrophoresis. In the 13 patients dying before 1957 the diagnosis of homozygous sickle-cell (SS) disease was based on a haemolytic anaemia with characteristic red cell morphology, the presence of the sickle-cell gene in both parents, or characteristic splenic pathology. Since 1967 the diagnosis of SS disease has been based on a single major haemoglobin band in the position of $\mathrm{Hb} S$ on alkaline and acid haemoglobin electrophoresis, $\mathrm{Hb} \mathrm{A_{2 }}$ levels between 1.5 and $4.0 \%$, and family studies where possible. The diagnosis of sickle-cell- $\beta^{\circ}$ thalassaemia $\left(S \beta^{\circ}\right.$ thal) was based on a similar electrophoretic pattern but with $\mathrm{Hb} \mathrm{A}$ levels above $4.5 \%$ and the presence of the $\beta$ thalassaemia trait in a parent or offspring. The diagnosis of sickle-cell- $\beta^{+}-$ thalassaemia $\left(S \beta^{+}\right.$thal) was based on the characteristic electrophoretic pattern with $20-30 \% \mathrm{Hb} \mathrm{A}$ and that of sickle-cell-haemoglobin C (SC)

\footnotetext{
Medical Research Council Laboratories (Jamaica), University of the West Indies, Kingston, Jamaica

ANTHONY N THOMAS, medical student

CATHERINE PATTISON, medical student

GRAHAM R SERJEANT, MD, FRCP, director
}

disease on the presence of two major haemoglobin bands in the position of $\mathrm{Hb} \mathrm{S}$ and $\mathrm{Hb} \mathrm{C}$ on alkaline and acid haemoglobin electrophoresis.

\section{Results}

There were 276 deaths (241 SS, $23 \mathrm{SC}, 7 \mathrm{~S} \beta^{+}$thal, $4 \mathrm{~S} \beta^{\circ}$ thal, 1 SO Arab disease) at ages ranging from 1 month to 76 years.

\section{HOMOZYGOUS SICKLE-CELL DISEASE}

The details in the 241 cases of SS disease are analysed further below.

\section{Age at death}

The age distribution at death (fig 1 ) shows the highest mortality to be in the younger age groups, nearly one-third dying in the first five years and the greatest mortality for any single year being in the first year. Since symptoms are unusual in the first six months, the youngest dying at 3 months from gastroenteritis and the next youngest at 5 months from pneumonia and congenital heart disease, most of this mortality occurred between six and 12 months.

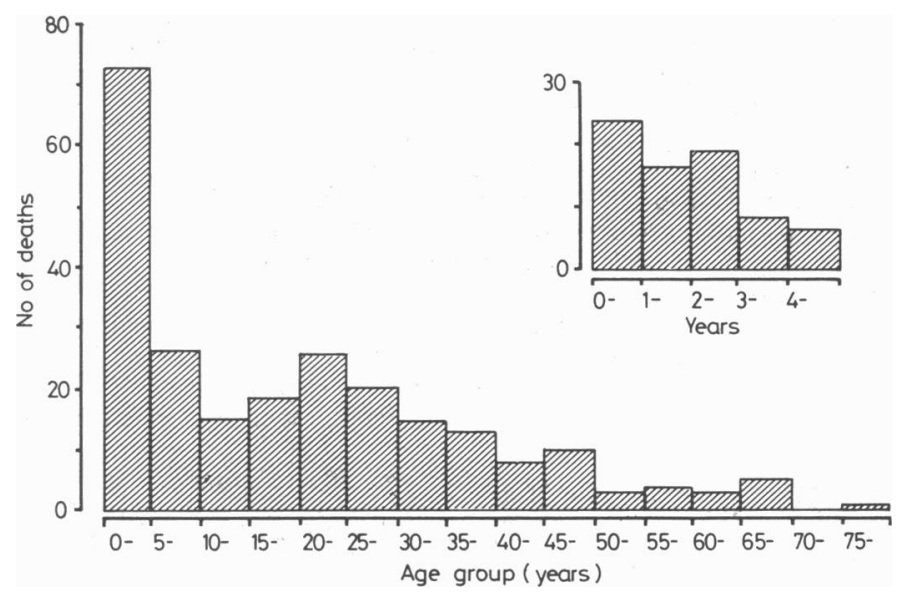

FIG 1-Age distribution of deaths in 241 cases of SS disease. Inset are details of first five years.

\section{Cause of death}

Of the 241 cases, the cause of death was ascertained in 199 ( 154 by detailed postmortem examination at the University Hospital, 45 by clinical history). The principal causes of death are ranked in order of frequency in table I, from which it may be seen that the most frequent were acute chest syndrome, acute splenic sequestration, renal failure, and meningitis. 
The acute chest syndrome (pneumonia or embolism or both) accounted for 60 deaths and affected about one-quarter of the cases in each age group. The great majority of these were apparently infective in origin, although histological evidence of pulmonary embolism occurred in 13 cases. Of these, the youngest was 20 months, one 19 years, four $20-29$, four $30-39$, and three over 40 , indicating that pulmonary embolism became an increasingly common cause of the acute chest syndrome in older age groups. Relevant factors associated with pulmonary embolism included pregnancy (massive pulmonary embolism occurring in a 19 year old three days postpartum

TABLE I-Cause of death by age in 241 cases of $S S$ disease

\begin{tabular}{|c|c|c|c|c|c|c|c|}
\hline \multirow{2}{*}{ Cause of death } & \multicolumn{7}{|c|}{ Age groups (years) } \\
\hline & $0-$ & $2-$ & $10-$ & $20-$ & $30-$ & $\geqslant 40$ & Total \\
\hline \multirow{2}{*}{$\begin{array}{l}\text { Acute chest syndrome } \\
\text { Acute splenic sequestration }\end{array}$} & $\begin{array}{ll}. & 13 \\
. & 15\end{array}$ & 11 & $\begin{array}{r}12 \\
0\end{array}$ & $\begin{array}{r}12 \\
0\end{array}$ & $\begin{array}{l}6 \\
0\end{array}$ & $\begin{array}{l}6 \\
0\end{array}$ & $\begin{array}{l}60 \\
23\end{array}$ \\
\hline & $\begin{array}{r}10 \\
\therefore \quad 0\end{array}$ & $\begin{array}{l}8 \\
1\end{array}$ & 3 & $\begin{array}{l}0 \\
9\end{array}$ & $\begin{array}{l}\mathbf{0} \\
\mathbf{3}\end{array}$ & $\begin{array}{l}0 \\
5\end{array}$ & $\begin{array}{l}23 \\
21\end{array}$ \\
\hline Meningitis & $\therefore$ & 10 & 0 & 2 & 1 & 1 & 18 \\
\hline Cardiovascular accident $\ldots$ & . & 4 & 3 & 1 & 3 & 3 & 14 \\
\hline Septicaemia $\quad \ldots$ & . & 5 & 0 & 2 & 2 & 0 & 13 \\
\hline Pregnancy related ..... & .. & 0 & 2 & 8 & 0 & 0 & 10 \\
\hline Rheumatic heart disease .. & .. & 0 & 3 & 2 & 2 & 2 & 9 \\
\hline No anatomical cause $\quad$. & . & 3 & 3 & 3 & 0 & 0 & 9 \\
\hline Aplastic crisis $\quad$.. & . & 4 & 1 & 0 & 0 & 0 & 7 \\
\hline Gastroenteritis & .. & 1 & 0 & 0 & 0 & 0 & 7 \\
\hline Other causes & . & 5 & 5 & 7 & 7 & 8 & 33 \\
\hline Total No of diagnoses ... & $\ldots 45$ & 52 & 32 & 46 & 24 & 25 & 224 \\
\hline Patients with two diagnoses & .. & 3 & 5 & 8 & 3 & 1 & 25 \\
\hline Patients without diagnoses & . & 9 & 7 & 8 & 7 & 10 & 42 \\
\hline Total No of patients & 41 & 58 & 34 & 46 & 28 & 34 & 241 \\
\hline
\end{tabular}

and in a 20 year old one day after caesarean section), rheumatic heart disease in a 32 year old, and possibly bed rest in a 46-year-old patient who developed a saddle embolus one day before being scheduled for total hip replacement. Of the 47 cases considered to have primarily bronchopneumonia, associated factors occurred in 17 and included acute splenic sequestration (1), congenital heart disease (1), rheumatic heart disease (2), malnutrition (2), renal failure (3), cerebrovascular accidents (3), pregnancy (2), postsurgical factors (1), tetanus (1), and amyloid secondary to tuberculosis of the spine (1).

Acute splenic sequestration, which occurred in 23 cases, was the commonest single cause of death in the first year and the second commonest cause in the whole series. Ten deaths occurred in the first year (6-11 months), five in the second, three in the third, two in the fourth, one in the fifth, and two in the seventh, the oldest child being 6 years 1 month. Factors associated with acute splenic sequestration were malnutrition (1), pneumonia (1), obstructive jaundice (1), pneumococcal septicaemia (2), and Haemophilus influenzae septicaemia (1).

Renal failure (21 cases) was predominantly a problem over the age of 20 years, although acute pyelonephritis occurred in two cases aged 6 and 17 years and the nephrotic syndrome occurred in two cases aged 12 and 16. Renal failure contributed to death in 17 of 95 $(18 \%)$ patients aged over 20 . Most affected patients over 30 manifested a progressive deterioration of renal function despite transfusion treatment for low haemoglobin concentrations, and necropsy showed shrunken end-stage kidneys in which the causative disorder was unknown. Six patients had diastolic blood pressures between 100-140 $\mathrm{mm} \mathrm{Hg}$ in association with chronic renal failure. Associated disease at necropsy included pneumonia (4), systemic lupus erythematosus (1), and cerebrovascular accidents (3).

Meningitis occurred in 18 cases and affected predominantly the younger patients, 14 cases being under age 8 , and others being affected at ages $20,23,35$, and 55 years. Organisms were isolated in 15 and included the pneumococcus (13), $H$ influenzae $B$ (1), and Salmonella typhimurium (1). A cerebrovascular accident was associated with meningitis in one 4 year old. Septicaemia presented a similar pattern of age involvement, nine out of 13 cases occurring before the age of 9 years, other cases occurring at 22, 24, 32, and 36 . Organisms included the pneumococcus (5), salmonella (3), staphylococcus (1), Escherichia coli (1), undefined Gram negative (2), and $H$ influenzae (1). Associated diagnoses included acute splenic sequestration in both children with pneumococcal septicaemia aged under 2 years.

Cerebrovascular accidents occurred in 14 cases and were generally associated with other diagnoses including pneumonia (3), meningitis (1), renal failure (3), and subarachnoid haemorrhage (3), two of which were associated with ruptured berry aneurysms. Four of the group dying with cerebrovascular accidents had had previous episodes.

Pregnancy was apparently related to death in 10 cases aged between $c$ 15 and 28. Two with postpartum pulmonary embolism and two with $\widehat{\Omega}$ pneumonia, one at 7 months' gestation and one postpartum, have $\overline{\bar{J}}$ been described above in the section on the acute chest syndrome. One, aged 26, died in childbirth but no necropsy was performed, $\mathbb{D}$ and another aged 15 died postpartum with toxaemia and severe hypertension. Three in whom adequate necropsies were not available $气$ died suddenly between the fourth and seventh months of pregnancy, and in one who died suddenly postpartum necropsy failed to show evidence of pulmonary embolism or the cause of death.

In nine patients aged $2 \frac{1}{2}-29$ years detailed necropsy examinations failed to find an anatomical cause of death. The results of blood $\overline{\overline{0}}$ cultures were not available in this group, and possibly some repre- $\frac{\sigma}{D}$ sented cases of overwhelming septicaemia.

Aplastic crises caused death in seven patients, six aged under 5 years and one aged 14. All presented to hospital dead or moribund and too late for effective treatment. Gastroenteritis caused mortality $\overrightarrow{0}$ only in young children, six out of seven cases being under 2 years. $\overrightarrow{\vec{H}}$ Other causes of death were rupture of the spleen (1), congenital $\vec{\omega}$ heart disease (1), unexplained pulmonary oedema (3), postoperative $\partial$ complications (3), gastrointestinal haemorrhage or perforation (3), $\underline{3}$ systemic lupus erythematosus (3), liver abscess, cirrhosis, or deep ī jaundice (6), malignant disease (3), accidental (5), emphysema (1), o amyloid (1), and unexplained congestive cardiac failure (3).

The relative importance of the most frequent causes of death in different age groups is summarised in fig 2 .

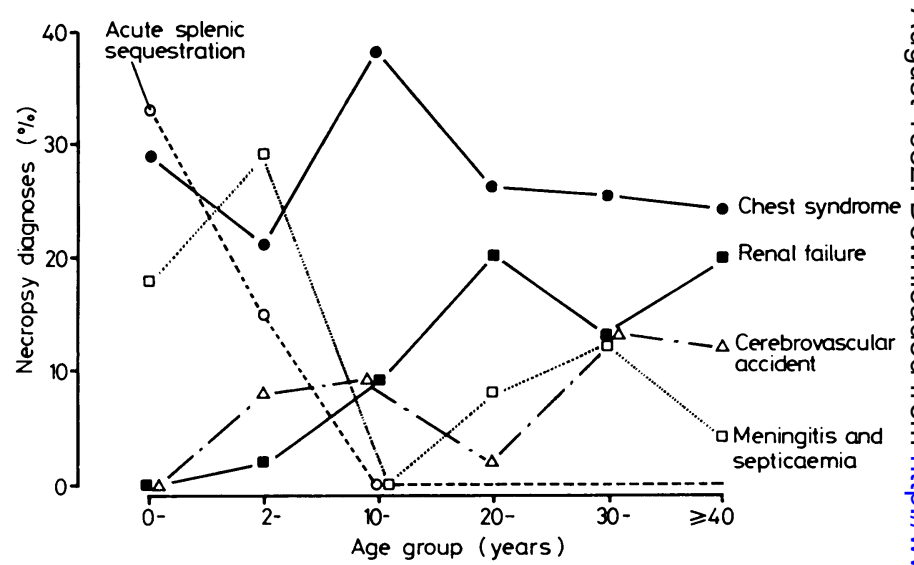

FIG 2-Relative frequencies of causes of death by age group in patients with SS disease.

\section{OTHER SICKLE-CELL SYNDROMES}

Details of death that were available in 21 cases of SC, six of $\mathrm{S}^{+}+\mathrm{N}$ thalassaemia, and three of $S \beta^{\circ}$ thalassaemia are summarised by age $G$ in table II. No details were available in two cases of SC disease $\frac{D}{O}$ dying at 71 and 72 , one with $S \beta^{+}$thalassaemia dying at 54, one with $S \beta^{\circ}$ thalassaemia dying at 13 , or in the case of SO Arab disease dying $N$ at 21 months.

TABLE II-Cause of death in $S C, S \beta+$ thalassaemia, and $S \beta^{\circ}$ thalassaemia. Numbers represent ages at death in years $(m=$ months $)$

\begin{tabular}{|c|c|c|c|c|}
\hline \multirow{2}{*}{ Cause of death } & & \multicolumn{3}{|c|}{ Genotype } \\
\hline & & SC & $S \beta^{+}$thal & $S \beta^{\circ}$ thal \\
\hline $\begin{array}{lll}\text { Pneumonia } & \ldots & \ldots \\
\text { Gastroenteritis } & \ldots & \ldots \\
\text { Acute splenic sequestration } \\
\text { Hepatic failure } \quad \ldots & \ldots \\
\text { Accidental.. } & \ldots & \ldots \\
\text { No anatomical cause } & \ldots \\
\text { Postoperative complications } \\
\text { Pregnancy related } \\
\text { Pneumococcal meningitis } \\
\text { Others } \quad . \quad\end{array}$ & $\begin{array}{l}\ldots \\
\because \\
\cdots \\
\cdots \\
\cdots \\
\cdots \\
\cdots\end{array}$ & $\begin{array}{c}2,34,34,56 \\
5 \mathrm{~m}, 1,2 \\
1,8 \\
14,18 \\
23,32 \\
6,31 \\
13,20 \\
\overline{50} \\
1 \mathrm{~m}, 18,43\end{array}$ & $\begin{array}{c}{ }^{8} \\
= \\
= \\
= \\
\frac{19}{51,54}\end{array}$ & $\begin{array}{l}\overline{ } \\
\frac{6,8}{41} \\
= \\
=\end{array}$ \\
\hline Total & $\ldots$ & 21 & 6 & 3 \\
\hline
\end{tabular}




\section{Discussion}

Because of the biases inherent in this study it is impossible to draw conclusions on life expectancy, and even the age distribution at death must be treated with caution. The apparent high mortality in the first few years of life may have been exaggerated by a cohort study of sickle-cell disease operative since 1973, which has identified almost all cases of SS disease at birth and ensured that most children dying in this study have had necropsies at the University Hospital. For example, this cohort study accounted for $15 / 24,7 / 16$, and $6 / 19$ children dying in the first, second, and third years in the present report. Nevertheless, survival curve analysis of data from this cohort study ${ }^{1}$ does support the pattern in fig 1 , which indicates the highest mortality occurring in the first year of life.

Causes of mortality showed some age-related patterns. Acute splenic sequestration, aplastic crises, gastroenteritis, septicaemia, and meningitis were predominantly paediatric problems. The first three were confined to children under 15 years whereas septicaemia and meningitis, although predominating in younger age groups, also caused a continuing but lesser mortality among adults. Renal failure and cerebrovascular disease both tended to be commoner in older patients, renal impairment being a common clinical feature in patients aged over $30 .^{2}$ The acute chest syndrome contributed to about $25 \%$ of deaths in all age groups, although pathological evidence of embolism or thrombosis was more frequent in older patients. The importance of pregnancy as an associated factor in 10 patients was unexpected and would have been underestimated from hospital experience. Four patients died suddenly at home while pregnant or immediately postpartum and no adequate necropsy information was available.

In view of the widespread interest in sickle-cell disease the paucity of comparable necropsy studies elsewhere is surprising. A review of 40 necropsies in West Africa ${ }^{3}$ was complicated by the lack of acceptable diagnostic techniques and by data suggesting that some patients may have had the sickle-cell trait. A review of 15 necropsies in $Z_{\text {ambia }}{ }^{4}$ identified infection and acute splenic sequestration as the major causes of death and confirmed the high early mortality in a study where the oldest patient was aged 9 years. Diggs ${ }^{5}$ in a retrospective review of necropsies in Memphis noted that $25 \%$ of deaths occurred in the first five years and that the predominant cause appeared to be infections. Clinical studies have also identified acute splenic sequestration $^{6}$ and meningitis and septicaemia ${ }^{7}$ as important causes of death among children in the United States.

Much could be learnt from comparative studies of necropsy information. Some features such as malaria and megaloblastic change from folate deficiency may simply reflect environmental differences. Others such as the mortality from acute splenic sequestration may reflect socioeconomic conditions in that possession of a telephone or private transport may allow earlier presentation to hospital when time is critically important. The contribution of infection might be expected to drop with improvement in diagnostic facilities and early appropriate treatment. With the control and removal of these acute complications the major determinants of mortality are likely to be a vaso-occlusive functional impairment of the lungs, heart, brain, and kidneys. The relative prevalence of such end organ damage in different areas may be informative about the epidemiology and genesis of such complications. It is important that such data be collected by necropsy whenever possible now that it is generally recognised that sickle-cell disease itself is not an acceptable explanation of death.

Much of this study would not have been possible without the excellent work of the departments of pathology and microbiology at the University Hospital of the West Indies.

\section{References}

${ }^{1}$ Rogers DW, Clarke JM, Cupidore L, Ramlal AM, Sparke BR, Serjeant GR. Early deaths in Jamaican children with sickle-cell disease. $B r$ Med $\mathcal{f} 1978 ; 1: 1515-6$.

2 Morgan AG, Serjeant GR. Renal function in patients over 40 with homozygous sickle-cell disease. $\mathrm{Br} \mathrm{Med} \mathcal{7} 1981$;282:1181-3.

${ }^{3}$ Edington GM. The pathology of sickle-cell disease in West Africa. Trans $R$ Soc Trop Med Hyg 1955;49:253-67.

4 Barclay GPT. A clinical and post mortem study of fatalities due to sickle cell anaemia. Med f Zambia 1970;6:229-38.

${ }^{5}$ Diggs LW. Anatomic lesions in sickle cell diseases. In: Abramson $\mathbf{H}$, Bertles JF, Wethers DL, eds. Sickle cell disease. Diagnosis, management, education and research. St Louis: CV Mosby, 1973:189-229.

${ }^{6}$ Seeler RA, Shwiaki MZ. Acute splenic sequestration crises (ASSC) in young children with sickle cell anemia. Clin Pediatr 1972;11:701-4.

${ }^{7}$ Overturf GD, Powars D, Baraff LJ. Bacterial meningitis and septicemia in sickle cell disease. Am $\mathcal{F}$ Dis Child 1977;131:784-7.

(Accepted 28 May 1982)

\section{A summer of euphemisms}

"He is due for a century any day." This used to be an oft-repeated comment from cricket commentators both on television and radio, whenever they referred to a certain erstwhile England cricket captain who, highly successful captain that he was, never managed to score a century in a test match; he was, I believe, in the team as a batsman too.

The English language is easily the best medium for euphemistic language. Appropriately enough, cricket, the sport the British were responsible for spreading all over the world, lends itself best to various forms of forced polite language, especially from the commentators. The first half of this summer's test cricket has been, personally speaking, a not-so-successful one (note the euphemism!) because I could hardly watch the performance of my team. At least things were not so bad on the radio, when commentators tried hard to say good things like, "He is always smiling"; "What a genial chap"; " $\mathrm{He}$ is a great one to have on a touring side-what a marvellous sense of humour, he has" etc, etc. It seems euphemistic language is resorted to more often by the radio commentators than their television counterparts, probably because the latter are well aware that people can actually see things for themselves and any amount of sugarcoating does not make the pill any sweeter. On the other hand, commentators, both on the radio and television, are fast running out of exultatory adjectives for $\mathrm{Mr}$ Botham.

Perhaps the best description on the radio was of the opening batsman who was bowled without even offering a stroke. "It's a Shakespearean tragedy," said one in "The Box." "A Comedy of Errors, I suppose," said another. "The ball actually didn't do much: A Midsummer Night's Dream - for the bowler, I mean," said Johnston, or was it Bailey ?"What do you think Fred ?" "As You Like It," said "Sir Frederick." I would have loved to hear what the commentators had to say when, many years ago, Benaud bowled May round his legs (the batsman also not offering a stroke, I believe) thereby changing the course of that test match.

Once again, personally speaking, I prefer to listen to Lewis, Trueman, Johnston and co when it is raining-it is less heartbreaking and sometimes even more interesting. However, I still do miss that Arlottian voice describing the game to his mother at home (I think that's what he said about cricket commentary). To take an objective view as a cricket lover who has wielded the willow at the "village green" level, I have a feeling that during the second of the test series against another subcontinental team, the commentators will be spared the embarrassment of having to strain for any more euphemisms this summer.-PRADIP K DATTA, consultant surgeon, Wick, Caithness. 